\title{
Laminae type and possible mechanisms for the formation of laminated sediments in the Shaban Deep, northern Red Sea
}

\author{
I. A. Seeberg-Elverfeldt ${ }^{1}$, C. B. Lange ${ }^{2}$, J. Pätzold ${ }^{1}$, and G. Kuhn ${ }^{3}$ \\ ${ }^{1}$ Research Center Ocean Margins, University of Bremen, P.O. Box 330440, 28334 Bremen, Germany \\ ${ }^{2}$ Center for Oceanographic Research in the eastern South Pacific (FONDAP-COPAS), Department of Oceanography, \\ University of Concepción, P. O. Box 160-C, Concepción, Chile \\ ${ }^{3}$ Foundation Alfred-Wegener-Institute for Polar and Marine Research, Columbusstrasse, 27568 Bremerhaven, Germany
}

Received: 9 May 2005 - Published in Ocean Science Discussions: 15 July 2005

Revised: 11 October 2005 - Accepted: 13 October 2005 - Published: 25 October 2005

\begin{abstract}
Laminated sediments in the Shaban Deep, a brinefilled basin in the northern Red Sea, were analyzed with backscattered electron imagery. Here we present possible mechanisms involved in the formation of laminae of various types and homogenous intervals arising from the detailed investigation of multicore GeoB $7805-1\left(26^{\circ} 13.9^{\prime} \mathrm{N}\right.$ and $35^{\circ} 22.6^{\prime} \mathrm{E}$; water depth $1447 \mathrm{~m}$ ) and gravity core $\mathrm{GeoB}$ $5836-2\left(26^{\circ} 12.61^{\prime} \mathrm{N}, 35^{\circ} 21.56^{\prime} \mathrm{E}\right.$; water depth $\left.1475 \mathrm{~m}\right)$. Sediment makeup includes six types: a) a laminated structure with alternating light (mainly coccoliths) and dark (diatom frustules) layers, where the diatom component is indicative of the intra-annual variability between stratification and mixing events; b) a pocket-like structure attributed to the sinking of particles within fecal pellets and aggregates; c) a matrix of tightly packed diatoms that relates to extended stratification/mixing periods of the water column; d) homogenous intervals that result from turbidity deposition; e) silt accumulations which origin may lie in agglutinated foraminifers; and f) pyrite layers with pyrite formation initiated at the seawaterbrine interface.
\end{abstract}

\section{Introduction}

The Shaban Deep, a brine-filled basin in the central axis of the northern Red Sea, has been the focus of our previous research on laminated sediments as recorders of abrupt changes in productivity and circulation for this region (SeebergElverfeldt et al., 2004a). The deep itself consists of four basins with near equal brine levels at about $1325 \mathrm{~m}$ water depth (Hartmann et al., 1998).
Previous work has dealt with the detailed composition of mid-Holocene to Last Glacial Maximum (LGM) laminated sediments from the southern basin of the Shaban Deep (core GeoB 5836-2; $26^{\circ} 12.61^{\prime} \mathrm{N}, 35^{\circ} 21.56^{\prime} \mathrm{E} ; 1475 \mathrm{~m}$ water depth) (Seeberg-Elverfeldt et al., 2004a). We showed that sediments encompassing the period 4-15 ka have a light and dark alternating pattern where light layers are mainly composed of coccoliths, terrigenous material of eolian origin and diatom fragments, and dark layers consist of almost exclusively diatom frustules (monospecific or mixed assemblage). It was further proposed that different diatom assemblages reflect changing conditions in stratification/mixing in the northern Red Sea (Seeberg-Elverfeldt et al., 2004a). This was discussed against the background of already existing paleoceanographic data from an oxic core from the northernmost Red Sea (GeoB 5844-2; $27^{\circ} 42.81^{\prime} \mathrm{N} ; 34^{\circ} 40.90^{\prime} \mathrm{E}$; $963 \mathrm{~m}$ water depth) (Arz et al., 2003). It was concluded that brine sediments from the Shaban Deep can be used for reconstructing paleoceanographic and paleoclimatic changes in the region at high resolution. Based on our detailed studies, schematic models of paleoflux scenarios for laminae formation at different time-slices were proposed.

In this study, we extend our previous records into the late Holocene and move one step further in our understanding of laminae formation within brine sediments. Very few studies exist that investigated the mechanism of sediment formation within brine environments. Erba et al. (1987) and Erba (1991) focused their work on laminated sediments from various anoxic brine-filled depressions in the Eastern Mediterranean Sea and discovered that "deep mid-water bacterial mats" are responsible for the formation of laminated sediments.

Correspondence to: I. A. Seeberg-Elverfeldt

(seeberg@uni-bremen.de)

(C) 2005 Author(s). This work is licensed under a Creative Commons License. 

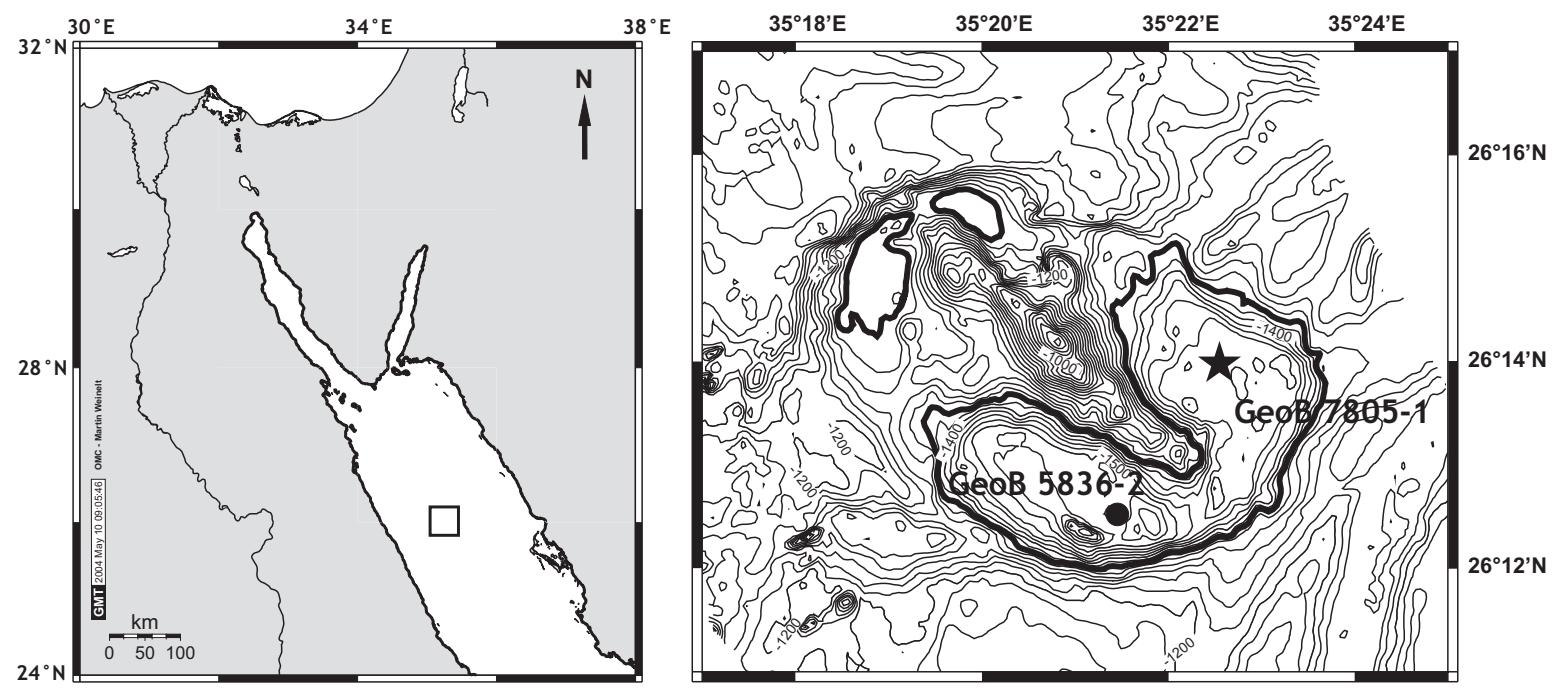

Fig. 1. Location of the Shaban Deep in the northern Red Sea (left panel) and of coring sites GeoB 7805-1 (asterisk) in the eastern basin and GeoB 5836-2 (filled circle) in the southern basin (right panel). Dark contour line on the right-hand panel indicates the depth of the modern brine surface.

We summarize within this study the different types of sediment structure preserved in Shaban Deep sediments of late Holocene through LGM age, and deliver possible mechanisms involved in their genesis.

\section{Study area}

As it is known from the literature, the Red Sea is a very unique environment. There are no permanent river inflows, rainfall is sparse and evaporation largely exceeds precipitation. The seawater exchange with the Arabian Sea in the south is limited due to the very shallow sill $(137 \mathrm{~m})$ of the Strait of Bab el Mandab (e.g. Edwards, 1987). The circulation is mostly driven by thermohaline forcing while wind forcing is only of minor importance. A description of the anti-estuarine circulation pattern of the Red Sea can be found in Eshel et al. (1994) and Eshel and Naik (1997).

The Red Sea plankton is characterized by the dominance of autotrophic picoplankton while larger cells are scarce in this region (Lindell and Post, 1995; Shaikh et al., 1986). Four different groups of phytoplankton are important in the annual cycle of the Red Sea (Shaikh et al., 1986): diatoms are present most of the year and are the predominant group in winter; blue-green algae (Trichodesmium spp.) and nanoplankton dominate in late spring and summer, and dinoflagellates in the fall. The diatom winter peak (December-February) is clearly dominated by Bacteriastrum, Chaetoceros, Nitzschia and Rhizosolenia (Shaikh et al., 1986). While the plankton is dominated by fragile forms (e.g. Nitzschia bicapitata group), surface sediments of oxic settings are enriched in robust taxa (e.g. Alveus marinus, Azpeitia neocrenulata, A. nodulifera and Roperia tesselata), and only anoxic brine sediments preserve the fragile diatoms to some extend (up to $26 \%$ of the assemblage; SeebergElverfeldt et al., 2004b).

\section{The Shaban Deep}

About 25 brine-filled deeps are found along the central axis of the Red Sea. The Shaban Deep (formerly named Jean Charcot Deep, Pautot et al., 1984) is one of these axial depressions in the northern Red Sea. It consists of four small basins (southern, eastern, northern and western; Fig. 1) that are separated by two ridges running N-S and W-E, respectively (Hartmann et al., 1998; Pautot et al., 1984). The basins have the seawater-brine interface (SBI), which has a thickness of only $\sim 2 \mathrm{~m}$, at nearly the same water depth $(\sim 1325 \mathrm{~m}$; Hartmann et al., 1998) and a salinity of about 260 psu. The high salinities are due to leaching of sub-bottom Miocene evaporites (Manheim, 1974). The top of Miocene evaporites (so called S-reflector) crops out within the brine basin at the modern level of the SBI (Pätzold et al., 2003; Pautot et al., 1984). The temperature within the brine is only slightly higher $\left(\sim 3^{\circ} \mathrm{C}\right)$ than the surrounding seawater (Hartmann et al., 1998). The density of the brine is about $1.2 \mathrm{~g} \mathrm{~cm}^{-3}$ (Millero et al., 1982). There is only minimal exchange (diffusion and convection) at the SBI (Hartmann et al., 1998). The brine body itself has a thickness of up to $200 \mathrm{~m}$, is almost depleted in dissolved oxygen $\left(<0.3 \mathrm{mg} \mathrm{L}^{-1}\right)$, and sulphide is absent (Hartmann et al., 1998). Methane concentrations increase sharply at the SBI and are several orders of magnitude higher within the brine than in the overlying seawater (Faber et al., 1998). No evidence for benthic life has been found, although a rich 


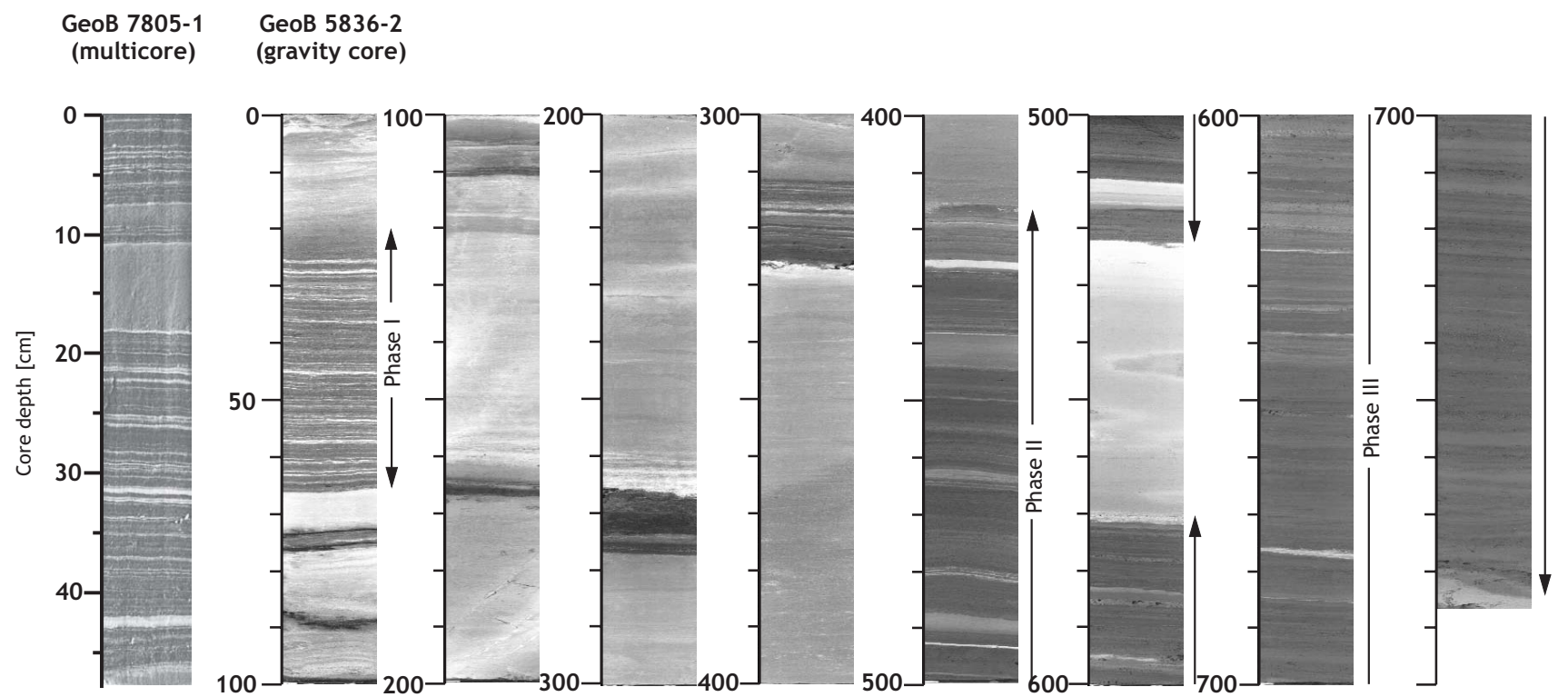

Fig. 2. General lithology of multicore GeoB 7805-1 (core photograph; $48 \mathrm{~cm}$ long) and gravity core GeoB 5836-2 (videologger data; $790 \mathrm{~cm}$ long) showing the distribution of laminated and non-laminated sediments. Phases I (4-6 ka), II (14-22 ka) and III (older than 34 ka) are indicated. Multicore GeoB 7805-1 encompasses the late Holocene.

prokaryotic community has been described to thrive at the SBI (Antunes et al., 2003; Eder et al., 2002). The Shaban Deep has been described as being hydrothermally active (e.g. Pautot et al., 1984), and Stoffers et al. (1990) found diagenetically-formed dolomite and rhodochrosite within organic rich layers in the sediments.

\section{Material and methods}

Two cores from the Shaban Deep were used in this study (Fig. 1): Gravity core GeoB 5836-2 was retrieved from the southern basin $\left(26^{\circ} 12.61^{\prime} \mathrm{N}, 35^{\circ} 21.56^{\prime} \mathrm{E} ; 1475 \mathrm{~m}\right.$ water depth; total length of core $=790 \mathrm{~cm}$ ) during $R V$ Meteor cruise M 44/3 in 1999 (Pätzold et al., 2000). This core was used in a previous investigation (Seeberg-Elverfeldt et al., 2004a), and results are re-analyzed here. Multicore GeoB 78051 from the eastern basin of the Shaban Deep $\left(26^{\circ} 13.9^{\prime} \mathrm{N}\right.$ and $35^{\circ} 22.6^{\prime} \mathrm{E} ; 1447 \mathrm{~m}$ water depth; total length of core $=$ $60 \mathrm{~cm}$ ) was collected during $R V$ Meteor cruise M 52/3 in 2002 (Pätzold et al., 2003). Because of its high water content and soupy texture, the multicore was left in cold storage $\left(4^{\circ} \mathrm{C}\right)$ for $\sim 12$ months. After this period, it had compacted down to $48 \mathrm{~cm}$ in length.

Both cores were logged with a Multi Sensor-Core-Logger (MSCL) with 3 Linescan CCD's Digital Imaging for determination of the color scale (Fig. 2). In addition, Fe was measured every $0.2 \mathrm{~cm}$ with an X-ray fluorescence (XRF) scanner on multicore GeoB 7805-1 (Fig. 3).

A general overview of sediment composition and texture was gained through smear slide analysis which followed standard ODP procedures.
The working halves of both cores were first sampled with "cookie cutters" of $15 \mathrm{~cm}(\mathrm{~L}) \times 1 \mathrm{~cm}(\mathrm{~W}) \times 5 \mathrm{~cm}$ (D) following the method described by Schimmelmann et al. (1990) and Dean et al. (1999). X-radiographs of slabs were taken to record differences in sediment density and structure. In this study, the X-radiograph negatives were scanned to establish a direct relationship with the thin sections that are described below. In the scanned negatives, light bands represent layers of very dense material and dark bands indicate layers of lower density.

Polished thin sections of resin-embedded sediment for gravity core GeoB 5836-2 were prepared from the cookie cutter slabs at the Cardiff University, Wales, following the methodology of Pike and Kemp (1996a) with one small modification: the samples were first soaked in deionized water to remove the salt before they were embedded. Details can be found in Seeberg-Elverfeldt et al. (2004a).

Polished thin sections of resin-embedded sediments from multicore GeoB 7805-1 were prepared at the GeoForschungsZentrum Potsdam, Germany (pers. comm., Köhler and Berger). There, $7 \mathrm{~cm}$ long samples were taken with a $3 \mathrm{~cm}$ overlap to the adjacent samples, shock-frozen with liquid nitrogen and freeze-dried for $48 \mathrm{~h}$. Afterward these sediment blocks were embedded stepwise under vacuum in Araldit 2020, a two-component epoxy resin.

All polished thin sections were carbon coated and studied using scanning electron microscopy (SEM). A Leo (Cambridge Instruments) S360 SEM with an Oxford Instruments INCA Wave elemental analysis system was used at Cardiff University and a Philips XL 30 ESEM was used at the Alfred-Wegener-Institute for Polar and Marine Research in 


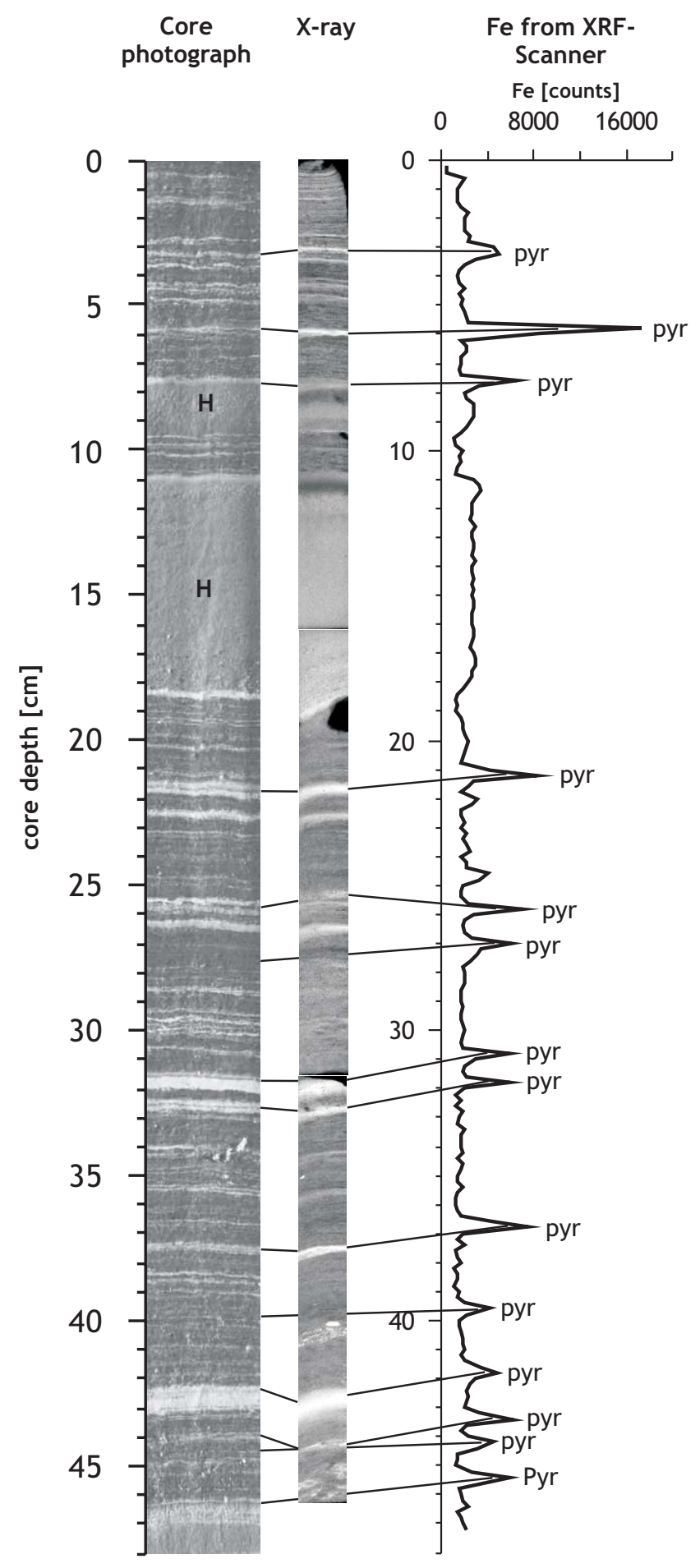

Fig. 3. Correlation between general lithology (left), X-radiography (middle) and Fe-intensities measured by XRF-scanner on multicore GeoB 7805-1. Pyrite layers (pyr) are located within prominent white layers (left) and are light in X-radiography (middle). $\mathrm{H}=$ homogenous intervals within the late Holocene.
Bremerhaven, Germany, both equipped with a backscatter detector. BSEI (backscattered electron imagery) mosaics were produced for every thin section. These photomosaics may be considered as porosity maps where porous diatomaceous sediment appears darker while terrigenous and calcareous sediment is less porous and therefore brighter. After first producing low magnification (30X for GeoB 5836-2 and 80X for GeoB 7805-1) BSEI photomosaics that act as basemaps of each sample, high resolution pictures at higher magnifications (up to $3500 \mathrm{X}$ ) were taken to study the composition of individual lamina in detail and to identify the species present.

\section{Results}

\subsection{General characteristics of Shaban Deep sediments}

Brine sediments from the Shaban Deep are "diatom-bearing nannofossil ooze, partly laminated, olive-gray to black, with varying contents of carbonate, opal, and terrigenous material, and with a very high content of hypersaline pore water" (Pätzold et al., 2000). Smear slide analysis reveal that sediments of both cores mainly consist of varying contents of coccoliths (sometimes coccospheres), diatoms, and terrigenous material. Foraminifers, pteropods, silicoflagellates and radiolarians are also present. Dominant coccolith species are Emiliania huxleyi, Gephyrocapsa oceanica and Aligosphaera robusta, while Umbilicosphaera sibogae, Helicosphaera sellii (?), Calcidiscus leptoporus and Florisphaera profunda are also present. The genus Amaurolithus is spread throughout the sediments, always sparse. The diatom assemblage is dominated by the genera Azpeitia, Bacteriastrum, Chaetoceros, Coscinodiscus, Nitzschia, Rhizosolenia, and Thalassionema.

Analyzed sediments of gravity core GeoB 5836-2 cover the time interval between 4 and $22 \mathrm{ka}$ (Seeberg-Elverfeldt et al., 2004a) while multicore GeoB 7805-1 encompasses the time interval between about 200 and $1700 \mathrm{yr}$ BP (SeebergElverfeldt et al., 2005).

Multicore GeoB 7805-1 is laminated with two prominent homogenous intervals between 7.6-9.5 cm and 10.9-18.4 cm (Fig. 3). Both homogenous intervals are bound at the top by a distinct bright layer and a slightly darker interval directly beneath it; the rest of each homogenous interval is lighter (greyish) than the laminated intervals in the core. Several prominent, very bright white layers of variable thickness are observed at 18.4-18.7 cm, 21.7-22.1 cm, 22.7-22.9 cm, 26.5$26.7 \mathrm{~cm}, 31.7-32.3 \mathrm{~cm}, 32.7-33 \mathrm{~cm}$ and $42.2-43 \mathrm{~cm}$. Most of them contain a blue/black layer which is located directly in the middle of the white layer or shifted towards the top. These blue/black layers show up white in the X-radiographs and correspond well with Fe-intensities measured with XRF (Fig. 3). It was previously established (Seeberg-Elverfeldt et al., 2004a) that these layers (dark within the sediment and light in X-radiograph and BSEI) are composed of coccoliths 
and framboidal pyrite. In addition, there are several yellowish layers present. The core ends with another homogenous interval starting at $46.2 \mathrm{~cm}$. This one also carries a bright layer at the top and a pyrite layer directly beneath it.

Core GeoB 5836-2 has three main laminated sections: 1) Phase I, from 21 to $65 \mathrm{~cm}$, representing 4-6 ka; 2) Phase II, from 417-525 cm, representing 13-22 ka; and 3) Phase III, from 572 to $785 \mathrm{~cm}$, encompassing sediments older than $\sim 34 \mathrm{ka}$. In addition, two small laminated intervals are present in the early Holocene (at 260-267 cm and 312.5$327.5 \mathrm{~cm}$ ). The laminated sections are separated by homogenous intervals of variable length. Moreover, several smaller homogenous layers are found within laminated Phase II (13 and $22 \mathrm{ka}$ ) (Fig. 2). In general, laminations are clearly visible in the mid-Holocene while they are fainter in Phases II and III (Fig. 2).

Pyrite layers are observed throughout the cores and their occurrence is more frequent in younger sediments. Also, some layers of Ca-rhodochrosite are seen in Lower Phase II sediments (18-19 ka) (Seeberg-Elverfeldt et al., 2004a).

\subsection{Detailed composition of Shaban Deep sediments}

\subsubsection{Biogenic components}

\section{Dark and light layers/pocket structure/matrix}

Thin section analysis revealed that the laminated (faintprominent) sediments of the Shaban Deep present three basic structures: a) alternating light and dark continuous layers (Fig. 4); b) a pocket-like structure where dark, discontinuous "layers" are embedded within the light material (Fig. 5); and c) a matrix of tightly packed diatoms (Seeberg-Elverfeldt et al., 2004a). The first two types are found in sediments younger than $15 \mathrm{ka}$ while the matrix type is characteristic of sediments dated 18-22 ka.

Large foraminifers, pteropods and radiolaria are embedded in late and mid-Holocene sediments disturbing the lamina fabric. Foraminifers decrease in number and size downcore and are absent from the matrix type sediments of 18 ka to LGM age.

\section{a) Type alternating light and dark continuous layers (Fig. 4)}

Light layers are comprised of coccoliths (sometimes coccospheres), terrigenous particles and diatom fragments (Fig. 6a). Dark layers on the other hand are comprised of either Proboscia/Rhizosolenia mats (Fig. 6b), aggregates of vegetative cells and setae from different species of Chaetoceros and Bacteriastrum, or a mixed Chaetoceros/Nitzschia/Thalassiosira assemblage (Fig. 6c) (Seeberg-Elverfeldt et al., 2004a).

\section{b) Type pocket-like structure (Fig. 5)}

Dark pockets are intermingled within the light material.
These pockets contain either a mixed diatom assemblage or an assemblage that is clearly dominated by Chaetoceros. The species that define the mixed assemblage are mostly delicate forms and are often hard to distinguish within the BSEI photomosaic (Fig. 6c).

Some dark pockets, especially within sediments from the late Holocene, are filled with material of unknown origin. At least in two cases that could be properly photographed, structures that resembled copepod remains could be recognized. Figure 6d shows this kind of material where part of a leg or maybe an antenna is observed. We therefore define these structures as chitinous copepod remains.

In addition to the diatom-dominated dark pockets or layers mentioned above there are others which appear light gray in the BSEI photomosaics; they are filled with well preserved coccospheres and coccolith plates as well as some diatoms (Fig. 6e).

\section{c) Type matrix}

Sediments are characterized by a matrix of tightly packed Rhizosolenia frustules (18-19 ka) or by a matrix dominated by resting spores of Chaetoceros (LGM) within which thick non-continuous layers of large centric diatoms (Coscinodiscus, Azpeitia, Stellarima, and Thalassiosira) and/or light pockets of coccoliths, terrigenous material, and diatom fragments are embedded (Seeberg-Elverfeldt et al., 2004a).

\section{Fecal pellets}

Light layers or pockets (coccolith/terrigenous) of all time intervals carry various amounts of fecal pellets ("fp" in Figs. 4 and 5). They are most abundant within late Holocene sediments where they sometimes appear in clusters (Fig. 7a); their number decreases sharply within Lower Phase II and LGM sediments. Two morphological types of fecal pellets can be distinguished: elliptical and small spheroids (Figs. 7a, b). Elliptical pellets are the most common type and they vary from circular/oval to elongate in cross section. They are mainly composed of coccolith plates, diatom fragments and small amounts of terrigenous particles (Fig. 7c).

We observed elliptical pellets in different stages of disintegration; while their shape and outline is clearly defined within younger sediments (Fig. 7d) they become quite diffuse in the older sections (Fig. 7e). Finally, when their structure breaks apart, they seem to blend into the light background (Fig. 7f).

The second type of pellet (spherical) contains more densely packed material. Again coccoliths and diatom fragments can be found within these pellets but also some material of unknown origin (Fig. 7b). Spheroids occur individually in all time intervals but most frequently in younger sediments.

Although we are not able to assign an origin to the pellets (they could have been produced by copepods and 


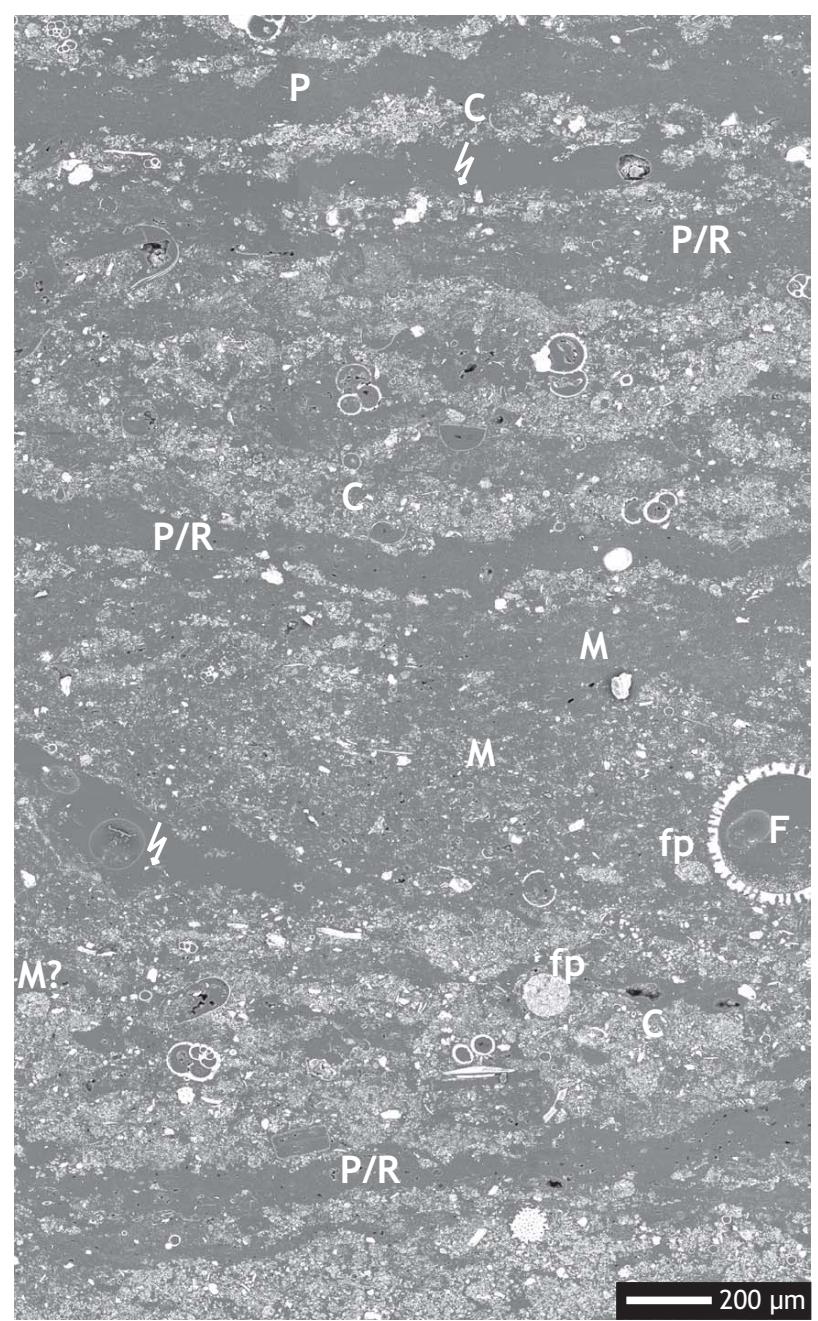

Fig. 4. BSEI photomosaic of thin section at $23.5 \mathrm{~cm}$ in multicore GeoB 7805-1. Alternating dark/light layers are shown which consist of Proboscia/Rhizosolenia (P/R), coccoliths, terrigenous material and diatom fragments $(C)$. Note that $P / R$ layers are continuous while "layers" with a mixed assemblage (M) are not. Fecal pellets (fp) and foraminifers (F) are present as well. White arrows indicate cracks.

Appendicularia (H. Gonzalez, pers. comm.)), the fact that copepod remains were found within our sediments supports our hypothesis of their pelagic origin.

\section{Homogenous intervals}

As stated above, several homogenous intervals are present within laminated sections (Fig. 2). In general, we distinguish two types of homogenous intervals. One type contains a mixture of coccoliths, terrigenous material, large centric diatoms and small foraminifers without sorting. The other type shows a gradation from coarser material at the bottom to finer grains at the top. One such example from the late

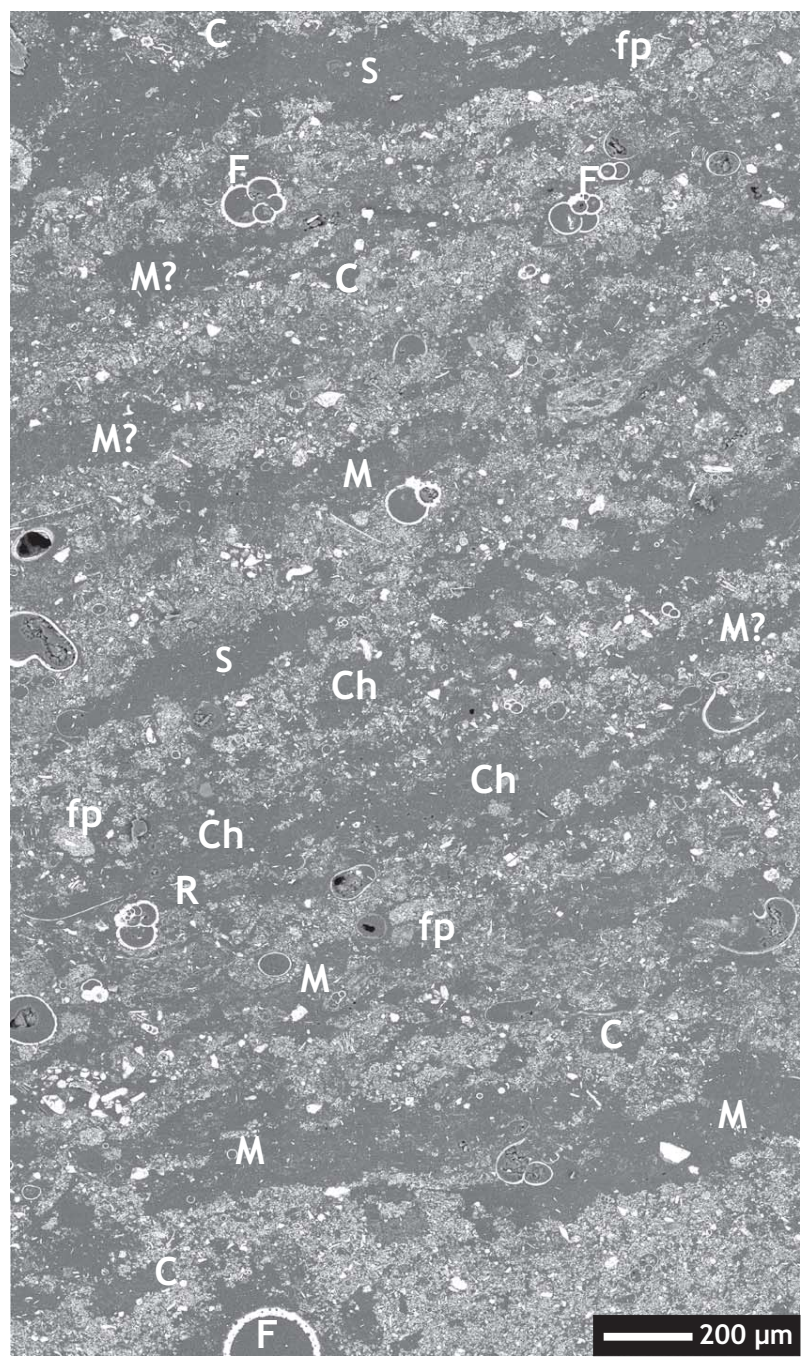

Fig. 5. BSEI photomosaic of thin section at $43.5 \mathrm{~cm}$ in multicore GeoB 7805-1, demonstrating pocket-like structure of the sediment. Dark pockets with a mixed assemblage (M), Chaetoceros vegetative cells $(\mathrm{Ch})$ or setae $(\mathrm{S})$ can be easily distinguished and are embedded within a light background (C) composed of coccoliths, terrigenous material and diatom fragments. Fecal pellets (fp), foraminifers (F) and one small cluster of Rhizosolenia (R) are also observed.

Holocene is given in Fig. 8. Here, we observe that large particles (foraminifers and pteropods) concentrate at the bottom of the homogenous interval. This is followed by a mixture of coccoliths, diatoms, terrigenous material and small foraminifers which occupies the largest part of the homogenous section. Above the mixed interval many large centric diatoms (e.g. Coscinodiscus spp.), coccoliths and terrigenous material occur; this has a darker appearance in the BSEI photomosaics. The homogenous interval ends with very fine grained material that consists of almost exclusively coccolith plates. This represents the distinct bright top boundary of the homogenous interval. 

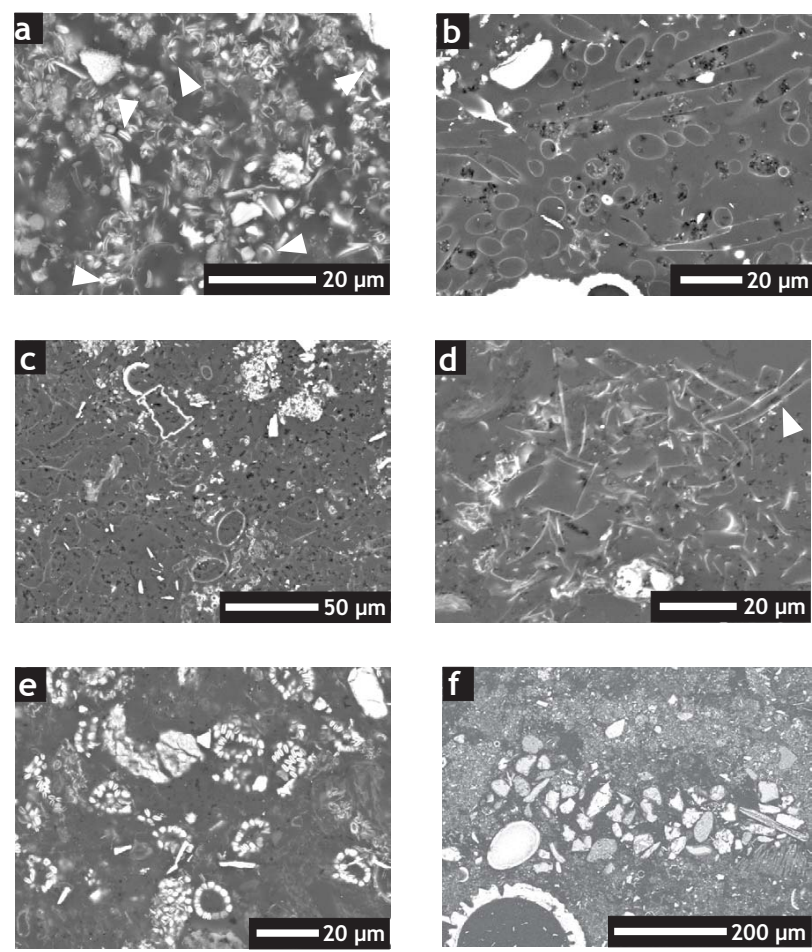

Fig. 6. BSEI photographs of selected laminae of multicore GeoB 7805-1 (a-e) and gravity core GeoB 5836-2 (f) showing examples of: (a) Coccoliths (arrowheads), terrigenous particles and diatom fragments within a light layer. (b) Proboscia, dark layer. (c) Example of mixed assemblage. (d) Chitinous remains of copepods. Small arrowhead points to antennae (or leg). (e) Coccospheres of Aligosphaera robusta within a "gray" pocket. (f) Silt accumulation.

\subsubsection{Abiogenic components}

\section{Silt accumulations}

A type of particle accumulation that is also present throughout the analyzed cores consists of clusters of larger silt grains, without developing the character of a lamina. Boundaries of these types are seldom sharp but they are easily distinguishable from the background material (Fig. 6f). These accumulations are composed of either a wide range of particle sizes (unsorted) or all the particles belong more or less to the same size fraction (sorted).

\section{Pyrite layers}

Episodic, up to $1 \mathrm{~mm}$ thick pyrite layers are present at all times except in the LGM. They are most frequent in younger sediments. Thin section analysis confirms the association of pyrite with BSEI light layers (Seeberg-Elverfeldt et al., 2004a). Pyrite grains can be positioned in the middle of a light layer or shifted towards the top of it (as in Holocene and Upper Phase II (13-15 ka) sediments), or they can be
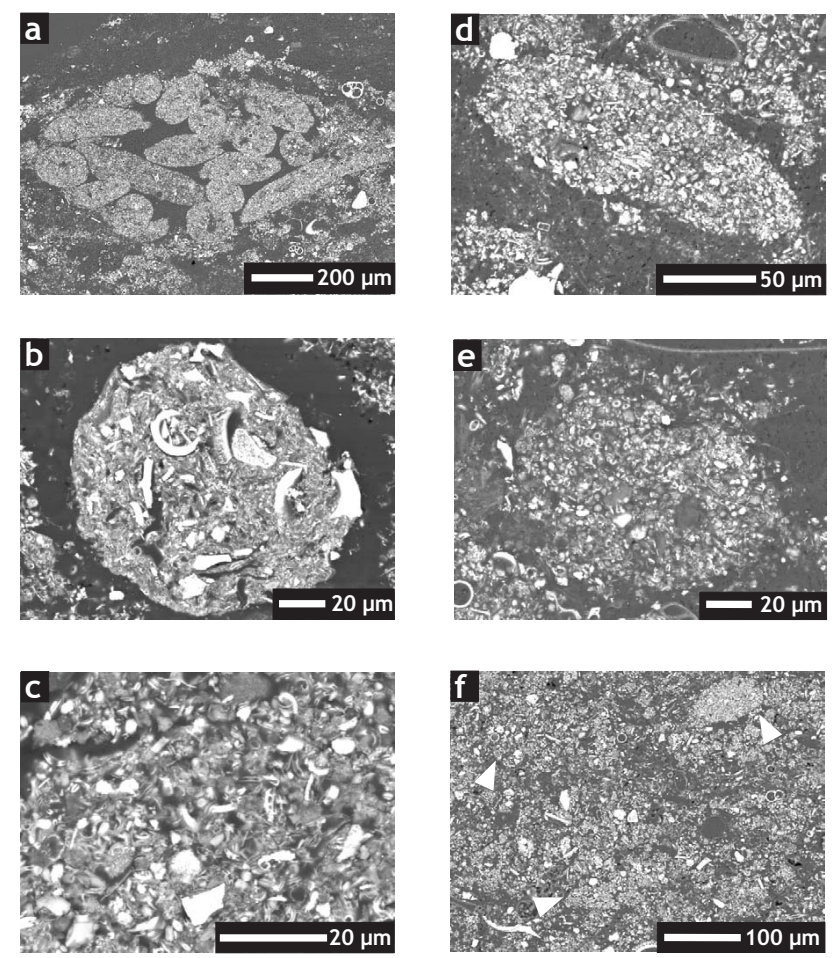

Fig. 7. BSEI photographs of fecal pellet types and composition in multicore GeoB 7805-1. (a) Cluster of elliptical fecal pellets. (b) Densely packed spheroid fecal pellet, composed of coccoliths, terrigenous particles and diatom fragments, as well as some material of unknown origin. (c) Detail of composition of elliptical pellet (coccoliths, terrigenous material and diatom fragments). (d-f) Sequence of disintegration of fecal pellets proposed as the mechanism to generate light layers. (d) Intact elliptical fecal pellet. (e) Disintegrating pellet. (f) Resulting light layer where the original shape of fecal pellet can still be recognized (arrowheads).

distributed randomly over the whole light material (as in Lower Phase II (18-19 ka) sediments). The amount and size of framboidal pyrite grains varies within these layers.

\section{Discussion}

In our previous study (Seeberg-Elverfeldt et al., 2004a) we were able to develop annual sedimentation models for Shaban Deep sediments of age 4-15 ka. We proposed that for the past $\sim 15000$ years, the laminations represent twoseason annual varves with light, coccolith-rich layers representing the summer flux and dark diatomaceous layers corresponding to late fall and winter production. Furthermore, it was suggested that Rhizosolenia-dominated layers are related to stratification of the water column while Chaetoceros-dominated layers account for mixing events. The frequency with which the pattern coccolith/Rhizosolenia couplets would be replaced by coccolith/Chaetoceros couplets was further used as indicative of the variability between 

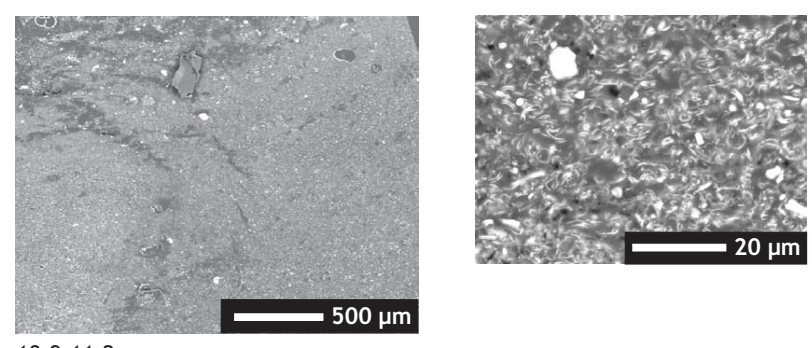

$10.9-11.2 \mathrm{~cm}$

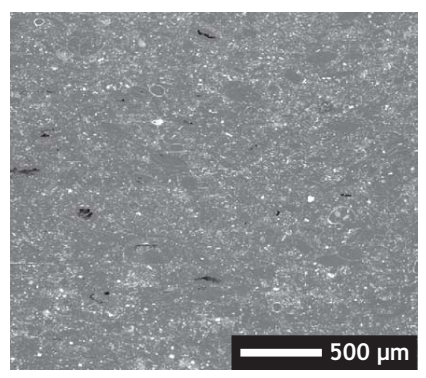

$11.3-11.6 \mathrm{~cm}$
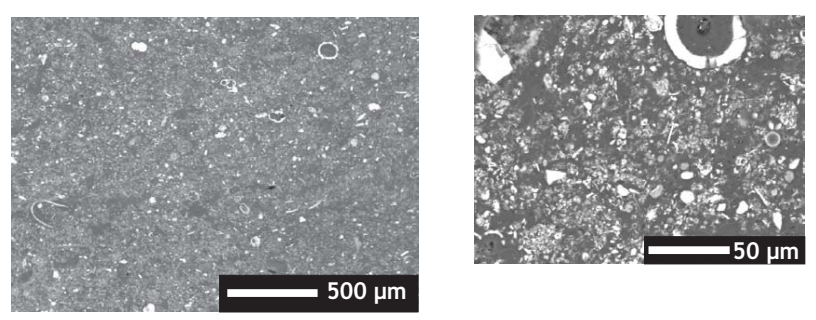

$12-17.5 \mathrm{~cm}$

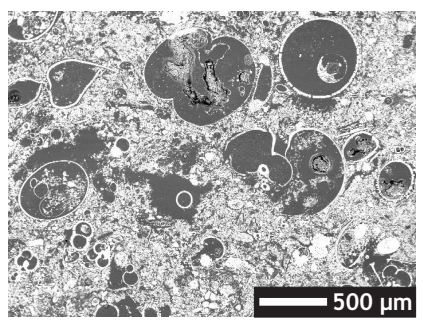

$17.6-18.4 \mathrm{~cm}$

Fig. 8. BSEI photographs of homogenous interval in the late Holocene (10.9-18.4 cm, multicore GeoB 7805-1). Left-hand panel shows the four different sequences discussed in the text (from bottom to top): coarse material (large foraminifers and pteropods) at the bottom, a mixture of coccoliths, diatoms, terrigenous material and small foraminifers on top of it, followed by a darker layer enriched in large centric diatoms. A pure coccolith layer bounds the homogenous interval at the top. High magnification photographs revealing detailed composition of the coccolith, diatom and mixed sequences are given on right-hand panel.

stratification and mixing events (Seeberg-Elverfeldt et al., 2004a). The new results for the late Holocene included here also suggest that an annual signal is preserved, and point to prevailing mixed conditions during this time. The dominant pattern in the late Holocene is that of dark pockets with a mixed diatom assemblage or a Chaetoceros-dominated assemblage being interrupted by short periods of stratification (Proboscia/Rhizosolenia layers).
For older sediments, where the carbonate signal is missing, we were not able to establish an annual sedimentation model (Seeberg-Elverfeldt et al., 2004a).

Studies by Erba et al. (1987) and Erba (1991) on laminated sediments from various anoxic brine-filled depressions in the Eastern Mediterranean Sea investigated the mechanisms of sediment formation within this unique environment. Sediments include discrete levels of gelatinous pellicles with abundant biogenic and inorganic particles within a matrix of organic matter (Erba et al., 1987) as well as large amounts of bacteria (Erba, 1991). These bacteria live on the seawaterbrine interface within "deep mid-water bacterial mats" and seem to form the organic matrix that entraps biogenic and inorganic remains (Erba, 1991). After the load of entrapped material increases to a certain point, these mats sink to the bottom of the basin and are therefore buried by sediments (see Fig. 13 in Erba, 1991; Erba et al., 1987). A second pathway for the mats to reach the basin floor includes the presence of turbidity currents which destroy the floating bacterial mats and transport fragments of the pellicles downwards (Erba, 1991).

The formation of laminated sediments within the Shaban Deep, northern Red Sea shows few similarities with these processes and is described in detail below. The sediment structure is different from the one described by Erba et al. (1987) and Erba (1991) and we found no evidence for a bacterial involvement in the formation of laminated sediments within the Shaban Deep.

5.1 Possible mechanisms for the formation of biogenic laminae

We present possible mechanisms involved in the formation of laminae of various types and homogenous intervals in Shaban Deep sediments (Figs. 9, 10). Our rationale behind the suggested scenarios includes several assumptions regarding transport processes through the water column and interpretation of the lamina fabric under BSEI: 1) particulate matter sinks relatively fast through the water column as fecal pellets, aggregates and/or diatom mats; 2) particulate matter then concentrates at the SBI due to the density gradient - until they are dense enough to break the interface - before sinking through the brine; 3 ) all particles that have accumulated at this interface might be subject to bacterial decomposition; 4) sorting may occur during accumulation at the SBI and during transport to the seafloor; 5) BSEI light layers are generated by the disintegration of fecal pellets carrying mainly coccoliths (and sometimes coccospheres); and 6) the paleoflux scenarios presented earlier (Seeberg-Elverfeldt et al., 2004a) are correct.

Our first type of sediment fabric, dark Rhizosolenia or Proboscia laminae coupled with light coccolith-rich ones, are found within the Holocene and the Upper Phase II sediments. The species in the diatomaceous lamina have been associated with mat development in a stratified water column and 
(a) Light and dark continuous layers
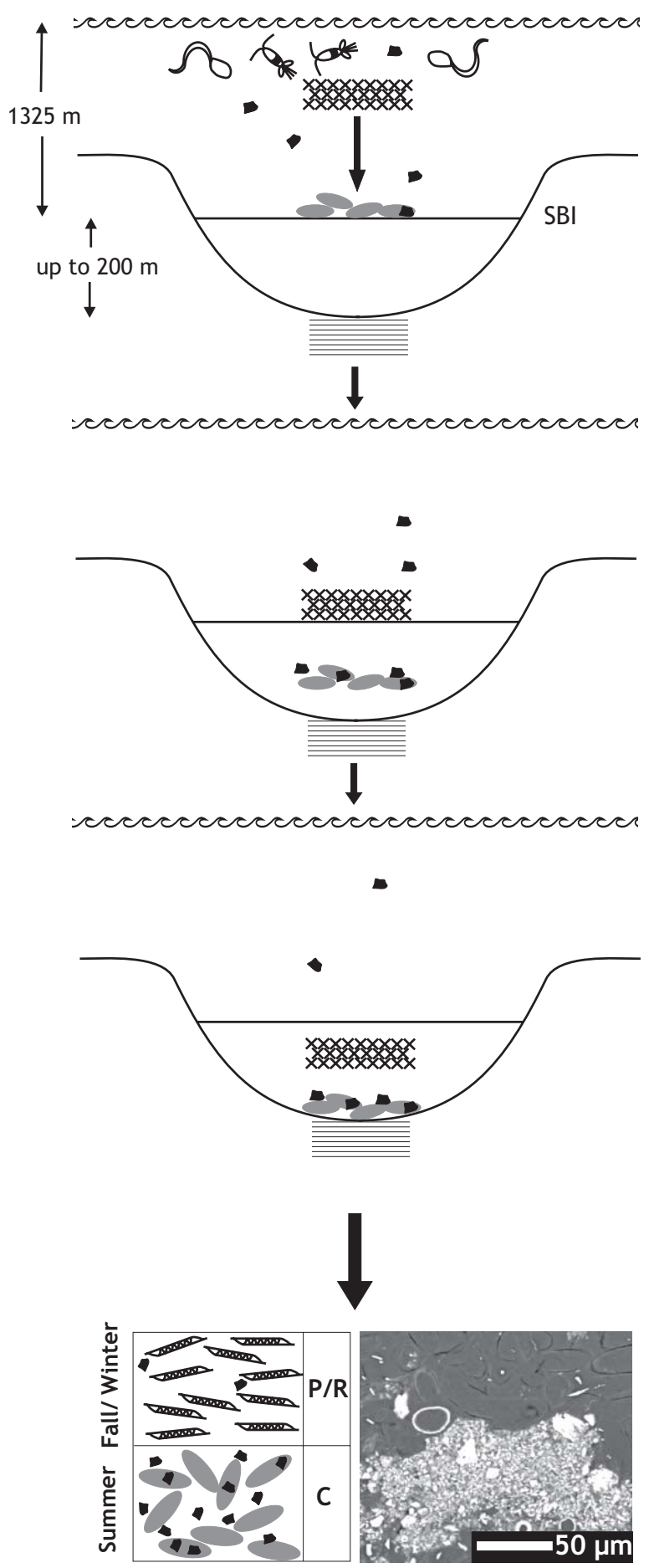

(b) Pocket-like structure

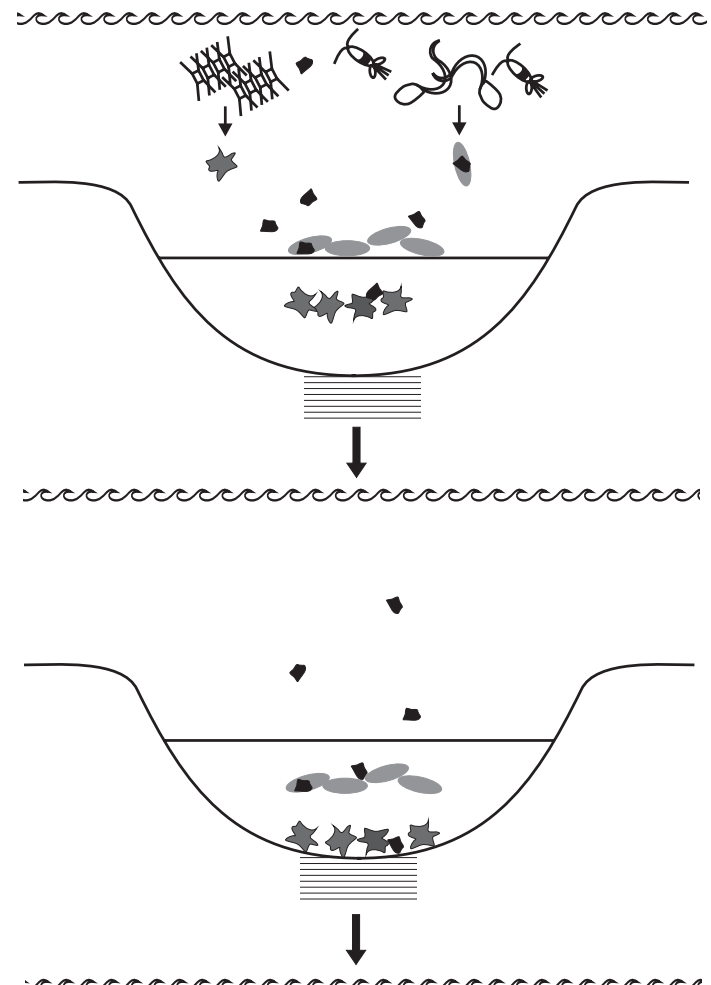

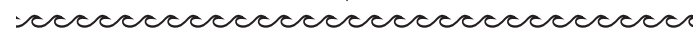

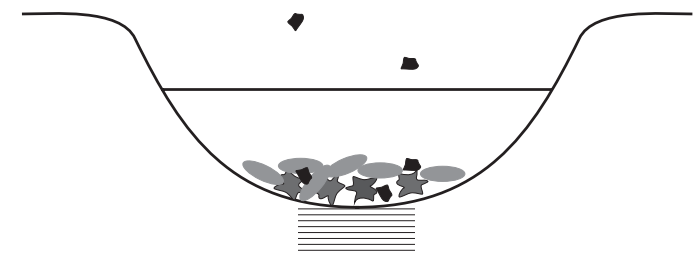

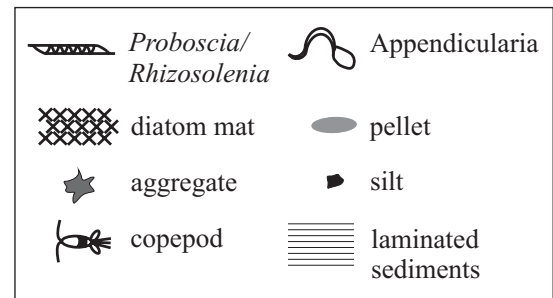

Fig. 9. Schematic diagrams of the proposed mechanism involved in the formation of light and dark continuous layers of coccolith/Rhizosolenia (Proboscia) couplets (a), and pocket-like structure (b) in laminated sediments of the Shaban Deep, northern Red Sea. See text for details. Specifications on water column depth, brine thickness and seawater-brine interface (SBI) are given in the first diagram only but also apply to Fig. 10. 
(a)Rhizosolenia matrix
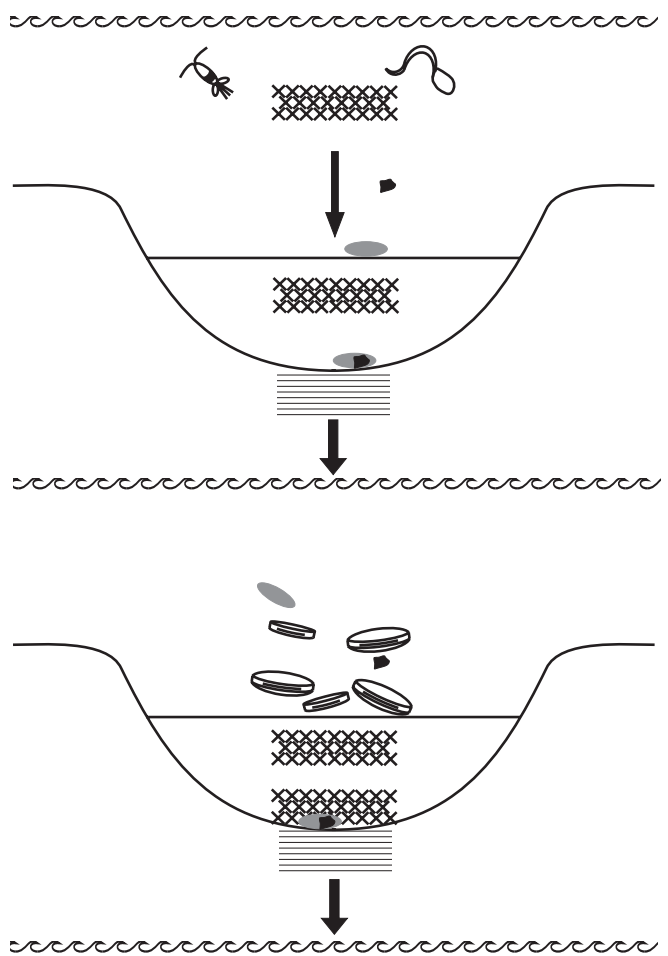

-

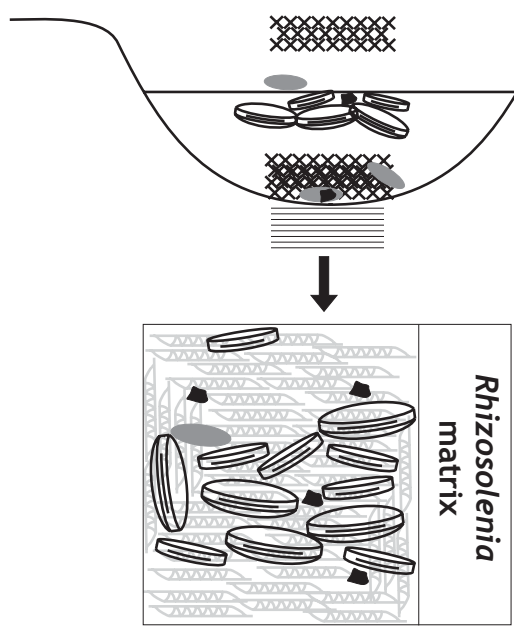

(b)Chaetoceros resting spore matrix
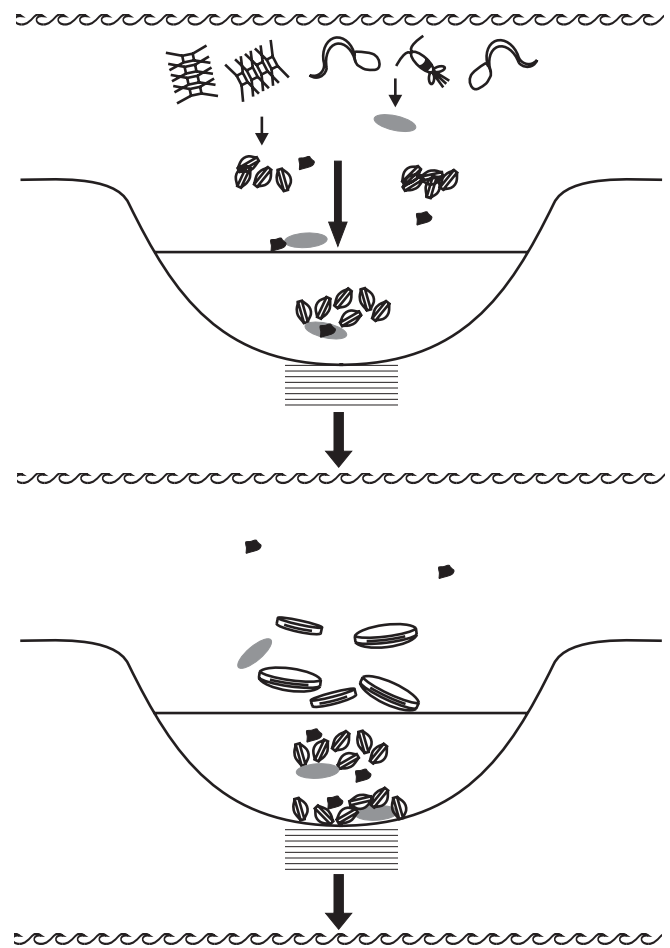

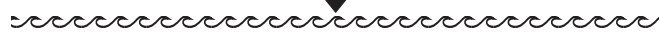
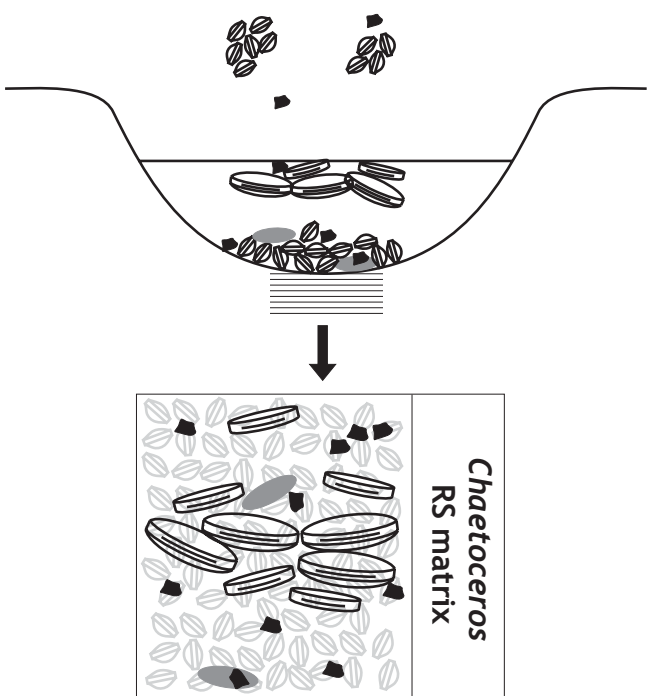

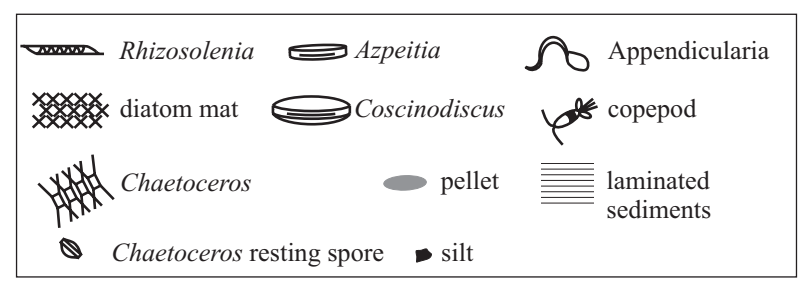

Fig. 10. Schematic diagrams of the proposed mechanism involved in the formation of a Rhizosolenia matrix characteristic of Lower Phase II (18-19 ka) sediments (a) and a Chaetoceros resting spore matrix found in LGM sediments (b). See text for detail. Specifications on water column depth, brine thickness and seawater-brine interface (SBI) are given in Fig. 9a. 
deposition during winter mixing (shade flora and fall dump of Kemp et al., 2000) while the calcareous type of lamina has been referred to as representing the summer flux of coccolithophorid blooms (Seeberg-Elverfeldt et al., 2004a).

Several steps are involved in the mechanism in reaching the alternating light and dark continuous lamina structure (Fig. 9a) of the sediments. We suggest that, first the summer bloom of coccolithophorids is consumed by copepods and/or Appendicularia that produce fecal pellets. These sink through the water column at speeds of $27-160 \mathrm{~m} \mathrm{~d}^{-1}$ (Yoon et al., 2001) and accumulate at the SBI until they become heavy enough to fall through it. Secondly, Proboscia/Rhizosolenia mats that have developed during the late fall, descend through the water column in winter when stratification breaks down. Mats sink fast $\left(1-4 \mathrm{~m} \mathrm{~h}^{-1}\right.$; Tracy Villareal pers. comm.) until they reach the SBI and accumulate there until they are able to break the interface. When mats are deposited on top of the fecal pellets lying on the basinfloor, the annually laminated sediments within the Shaban Deep are generated.

Our second sediment fabric is the pocket-like structure found mainly within late Holocene sediments, resulting from the deposition of diatomaceous aggregates and coccolith-rich fecal pellets. As it was stated before, these pockets contain a mixed diatom assemblage that is mainly associated with species of Chaetoceros. This genus is known for polysaccharide exudation and aggregation into transparent exopolymer particles (TEPs) (Alldredge et al., 1993). Flocs of Chaetoceros sink through the water column with speeds of 50$200 \mathrm{~m} \mathrm{~d}^{-1}$ (two orders of magnitude faster than individual Chaetoceros cells) (Alldredge and Gotschalk, 1989).

The basic mechanisms involving sinking and deposition explained above can also be applied for the formation of the pocket-like structure (Fig. 9b) with Chaetoceros-aggregates (that also include other diatom species) representing the winter production, and fecal pellets the consumption of the summer bloom of coccolithophorids. Since the deposited material is a mixture of different transporting agents, no clear continuous laminae can develop. However, we suggest that over time, this pocket-like structure gets compacted to generate the coccolith/Chaetoceros laminae observed in Upper Phase II (13-15 ka) sediments.

The third type of structure, a matrix of tightly packed diatom frustules characteristic of sediments of age $18 \mathrm{ka}$ - LGM, relies on the same overall mechanisms described above but due to the lack of the coccolith carbonate component an annual signal could not be defined (SeebergElverfeldt et al., 2004a). It is known that during this time frame Red Sea sediments are characterized by a so-called "aplanktic zone" attributed to high salinities ( $>50 \mathrm{psu}$; Arz et al., 2003) not favorable for planktonic foraminifer growth (e.g. Hemleben et al., 1996), and severe carbonate dissolution (Arz et al., 2003). Taking this into account, we would expect that fecal pellets rich in coccolithophorids were still produced in the water column but due to the severe condi- tions for carbonate preservation most of them would have been dissolved.

For the Rhizosolenia matrix (Fig. 10a) characteristic of Lower Phase II (18-19 ka) sediments, we suggest that the transportation pathway via mats to the brine-floor is the same as in the Holocene. For generating the Chaetoceros matrix characteristic of LGM sediments, long periods of intense mixing and/or higher nutrient availability was assumed (Seeberg-Elverfeldt et al., 2004a). We suggest that large flocs (possibly TEPs) of Chaetoceros resting spores were produced in the water column and after accumulation on the SBI sank down to the basin floor (Fig. 10b). Both time intervals also show thick non-continuous layers of large centric diatoms that could have either first accumulated on the SBI or have descended directly to the bottom as large aggregates (Figs. 10a, b).

The role that the seawater-brine interface plays in the formation of these special sediment fabric types is still unclear. In our models, we attributed an "accumulating role", that is, particulate matter gets concentrated at the SBI due to density gradients. We believe that the most important aspect in the laminae formation is the productivity signal in the photic zone. The type sinking material and its structure (e.g. diatoms in aggregates or in mats, fecal pellets) determines the sediment fabric that can be found in the basin itself. Future studies would have to include the use of remotely operated vehicles at different times of the year and sediment traps at various depths to help understand the processes that take place at this special boundary layer and its role in the sedimentation process.

5.2 Possible depositional sequence of homogenous intervals

Some of the investigated homogenous intervals showed a clear gradation while others were like an assortment of unsorted material. Especially the two homogenous intervals during the late Holocene show the clear characteristics of turbidites (e.g. Reineck and Singh, 1980).

The Shaban Deep is part of the tectonically active axial depression where the African and Arabian plate are slowly drifting apart (e.g. Braithwaite, 1987). These movements cause underwater earthquakes that mobilize the sediment that is deposited on the slope.

The southern and eastern basins of the Shaban Deep itself have very steep slopes along the central ridge. The other slopes are gentler in the eastern basin (Fig. 1). Both basins are surrounded by a carbonate crust which possibly originates from oxidation of methane around the SBI (Pätzold et al., 2003). Only a small amount of sediment can collect on this crust. We suggest that even small tectonic movements can cause this material to slide down the slope. This turbidity current could either a) slide right into the brine pool as a slump; or b) flow separation may occur with coarse material streaming downslope and finer material moving on top 
of the SBI (McCave, 1972). This will disturb the interface and sinking turbiditic material will collect the biogenic particles that have already accumulated on the SBI. The scenario of flow separation of turbidites was earlier described for the brine-filled Bannock Basin (Eastern Mediterranean) by Corselli and McCoy (1989), and could explain the gradation of homogenous intervals within late Holocene and LGM Shaban Deep sediments (Fig. 8).

\subsection{Possible origin of silt accumulations}

The above described accumulations of silt particles (sorted and unsorted) could be associated with agglutinated foraminifers (J. Pike, pers. comm.). Berggren and Boersma (1969) found low abundances of some benthic foraminifers (including agglutinated species) within Red Sea brine cores. However, preserved shells of agglutinated foraminifers were not observed within any of our investigated sediments from the Red Sea.

Pike and Kemp (1996b) identified silt aggregates in anoxic laminated sediments from the Guaymas (Gulf of California) and Santa Barbara basins as remains of agglutinated foraminifers. Brodie and Kemp (1995) also mentioned "silt pellets" within the Peruvian upwelling sediments that show the same characteristics as our accumulations of silt grains. These authors describe them as either consisting of "a wide range of grain sizes, or almost exclusively of small grains (under $20 \mu \mathrm{m}$ in size)" and assigned their origin to remains of agglutinated foraminifers.

Pike and Kemp (1996b) describe a model for the formation of these accumulations that includes the collection of silt grains of different sizes by the individual foraminifer into a detritic cover, where smaller grains are used to build a new chamber while larger particles are used for protection. After finishing the new chamber, the foraminifer leaves a pile of coarser grains behind which are then preserved within the sediment (Pike and Kemp, 1996b). This model is based upon investigations of Bender (1992) on the chamber formation of Textularia candeiana.

It is not likely that agglutinated foraminifers are able to live within the sediments of the brine basin since the brine is anoxic at all times. However, organisms could get transported from the slopes of the basin and since they are not able to survive in this special environment, leave the remains of their chambers behind.

\subsection{Possible origin of pyrite layers}

Pyrite layers of all investigated intervals were always associated with coccolith layers and secondary formed carbonate was not present. Hübner (2002) investigated sediments from the brine-filled Urania Basin (eastern Mediterranean) and suggested that pyrite formation started at the SBI. Filter samples from Meteor cruise M 52/3 (2002) from the SBI con- tained amorphous Fe-oxides but no Fe-monosulfides were found (M. Schmidt, pers. comm.).

Although we are unable to deliver a specific model for the formation of pyrite layers we suggest that the first step in the formation of pyrite occurs at the SBI under certain environmental conditions that permit the formation of amorphous monosulfides. These conditions include a) a high content of organic matter; b) hydrogen sulfide, produced during sulfate reduction; c) elemental sulfur availability; and d) bacterial oxidation of methane at the SBI. The final transformation of monosulfides to framboidal pyrite takes place either at the brine-sediment interface or within the sediment after deposition.

\section{Conclusions}

Backscattered electron microscopy of polished thin sections reveals that Shaban Deep sediments include six different types of sediment fabric:

- Alternating light and dark continuous layers composed of coccoliths/diatom couplets;

- A pocket-like structure composed of diatom aggregates embedded within light material (coccoliths and terrigenous material);

- A matrix of tightly packed diatoms;

- Homogenous intervals due to turbidity events;

- Silt accumulations; and

- Pyrite layers

The former three structures and their composition result from a combination of biogenic production in the water column and eolian input into the Red Sea, and a sequence of events that include: a) fast sinking through the water column in the form of aggregates, fecal pellets and diatom mats; b) accumulation of particles at the SBI; c) sorting during settling through the brine; and d) preservation in the sediment.

Silt accumulations are thought to be the remains of agglutinated foraminifers. The formation of framboidal pyrite may be initiated at the SBI.

Acknowledgements. We thank the captain and crew of $R / V$ Meteor for their efforts and support at sea. We also acknowledge the generous grant of permission for conducting research in the territorial waters of the Kingdom of Saudi Arabia. Thanks are extended to the technicians of the GFZ Potsdam and the Cardiff University for the preparation of thin sections and to U. Bock (AWI) and P. Fisher (Cardiff University) for their help with the SEM. We also acknowledge the help of H. Pfletschinger with XRF measurements. Special thanks go to $\mathrm{S}$. Kasten for helpful comments on the genesis of pyrite, to H. González for discussion on fecal pellet composition and origin, to T. Villareal for discussion on Rhizosolenia sinking speeds, and to J. Pike for her help with agglutinated foraminifers. 
We also want to thank A. Ehrhardt from the Center for Marine and Climate Research Institute for Geophysics (University of Hamburg) for creating the bathymetric map of the Shaban Deep (Fig. 1) from bathymetric grid data of RV Meteor Cruises 44/3 and $52 / 3$. This manuscript benefited from helpful comments of two anonymous reviewers. We are very grateful to the Hanse Institute of Advanced Study, Delmenhorst, Germany, for the Fellowship awarded to C. B. Lange. This work was supported by the Deutsche Forschungsgemeinschaft as part of the DFG-Research Center "Ocean Margins" at the University of Bremen, No. RCOM0341.

Edited by: A. Kemp

\section{References}

Alldredge, A. L. and Gotschalk, C. C.: Direct observations of the mass flocculation of diatom bloom: characteristics, settling velocities and formation of diatom aggregates, Deep-Sea Res., 36(2), 159-171, 1989.

Alldredge, A. L., Passow, U., and Logan, B. E.: The abundance and significance of a class of large, transparent organic particles in the ocean, Deep-Sea Res. I, 40(6), 1131-1140, 1993.

Antunes, A., Eder, W., Fareleira, P., Santos, H., and Huber, R.: Salinisphaera shabanensis gen. nov., sp. nov., a novel, moderately halophilic bacterium from the brine-seawater interface of the Shaban Deep, Red Sea, Extremophiles, 7, 29-34, 2003.

Arz, H. W., Pätzold, J., Müller, P. J., and Moammar, M. O.: Influence of Northern Hemisphere climate and global sea level rise on the restricted Red Sea marine environment during Termination I, Paleoceanography, 18(2), 1053, doi:10.1029/2002PA000864, 2003.

Bender, H.: Chamber formation and biomineralization in Textularia candeiana D’Orbigny (Sarcodina: Textulariina), J. Foram. Res., 22(3), 229-241, 1992.

Berggren, W. A. and Boersma, A.: Late Pleistocene and Holocene Planktonic Foraminifera from the Red Sea, in: Hot Brines and Recent Heavy Metal Deposits in the Red Sea, edited by: Degens, E. T. and Ross, D. A., Springer Verlag, New York, 282298, 1969.

Braithwaite, C. J. R.: Geology and Palaeogeography of the Red Sea Region, in: Key Environments: Red Sea, edited by: Edwards, A. J. and Head, S. M., Pergamon Press, Oxford, 22-44, 1987.

Brodie, I. and Kemp, A. E. S.: Pelletal structures in Peruvian upwelling sediments, J. Geol. Soc., 152, 141-150, 1995.

Corselli, C. and McCoy, F. W.: Sedimentation of organic matter, Bacino Bannock, in: Anoxic Basins of the Eastern Mediterranean, edited by: Cita, M. B., Camerlenghi, A., and Corselli, C., Ric. Sci., Suppl., 72, 50-53, 1989.

Dean, J. M., Kemp, A. E. S., Bull, D., Pike, J., Patterson, G., and Zolitschka, B.: Taking varves to bits: Scanning electron microscopy in the study of laminated sediments and varves, J. Paleolimn., 22, 121-136, 1999.

Eder, W., Schmidt, M., Koch, M., Garbe-Schönberg, D., and Huber, R.: Prokaryotic phylogenetic diversity and corresponding geochemical data of the brine-seawater interface of the Shaban Deep, Red Sea, Environ. Microbiol., 4(11), 758-763, 2002.

Edwards, F. J.: Climate and Oceanography, in: Key Environments: Red Sea, edited by: Edwards, A. J. and Head, S. M., Pergamon Press, Oxford, 45-70, 1987.
Erba, E.: Deep mid-water bacterial mats from anoxic basins of the Eastern Mediterranean, Mar. Geol., 100, 83-101, 1991.

Erba, E., Rodondi, G., Parisi, E., Ten Haven, H. L., Nip, M., and de Leeuw, J. W.: Gelatinous pellicles in deep anoxic hypersaline basins from the eastern Mediterranean, Mar. Geol., 75, 165-183, 1987.

Eshel, G., Cane, M. A., and Blumenthal, M. B.: Modes of subsurface, intermediate, and deep water renewal in the Red Sea, J. Geophys. Res., 99(C8), 15 941-15 952, 1994.

Eshel, G. and Naik, N. H.: Climatological Coastal Jet Collision, Intermediate Water Formation, and the General Circulation of the Red Sea, J. Phys. Oceanogr., 27, 1233-1257, 1997.

Faber, E., Botz, R., Poggenburg, J., Schmidt, M., Stoffers, P., and Hartmann, M.: Methane in Red Sea brines, Org. Geochem., 29(1-3), 363-379, 1998.

Hartmann, M., Scholten, J. C., Stoffers, P., and Wehner, F.: Hydrographic structure of brine-filled deeps in the Red Sea - new results from the Shaban, Kebrit, Atlantis II, and Discovery Deep, Mar. Geol., 144, 311-330, 1998.

Hemleben, C., Meischner, D., Zahn, R., Almogi-Labin, A., Erlenkeuser, H., and Hiller, B.: Three hundred eighty thousand year long stable isotope and faunal records from the Red Sea: Influence of global sea level change on hydrography, Paleoceanography, 11(2), 147-156, 1996.

Hübner, A.: Geochemische und mineralogische Untersuchung von Sedimenten aus dem Bereich des anoxischen, hypersalinen Urania-Beckens (östliches Mittelmeer) zur Charakterisierung von mariner Sedimentation unter extremen Bedingungen, $\mathrm{PhD}$ Thesis, Free University of Berlin, Berlin, 104 pp., 2002.

Kemp, A. E. S., Pike, J., Pearce, R. B., and Lange, C. B.: The "Fall dump" - a new perspective on the role of a "shade flora" in the annual cycle of diatom production and export flux " Deep-Sea Res. II, 47, 2129-2154, 2000.

Lindell, D. and Post, A. F.: Ultraphytoplankton succession is triggered by deep winter mixing in the Gulf of Aqaba (Eilat), Red Sea. Limnol. Oceanogr., 40(6), 1130-1141, 1995.

Manheim, F. T.: Red Sea geochemistry, Initial Report DSDP, 23, 975-998, 1974.

McCave, I. N.: Transport and escape of fine-grained sediment from shelf areas, in: Shelf sediment transport, edited by: Swift, D. J. P., Duane, D. B., and Pilkey, O. H., Dowden, Hutchinson, Ross, Stroudsburg, PA, 225-248, 1972.

Millero, F. J., Mucci, A., Zullig, J., and Chetirkin, P.: The density of Red Sea brines, Mar. Chem., 11, 463-475, 1982.

Pätzold, J., Abd El-Wahab Farha, O., Abu-Ouf, M., Al Hazmi, Y. M. M., Al-Rousan, S., Arz, H. W., Bagabas, K. A. A., Bassek, D., Blaschek, H., Böke, W., Donner, B., Eder, W., Felis, T., Gayed, H. Y. K., Gutowski, M., Hemleben, C., Hübner, H., Hübscher, C., Kadi, K. A., Kästner, R., Klauke, S., Körner, S. O., Kuhlmann, H., Lützeler, T., Meier, S., Melegy, M. M., Moammar, M. O., Mohamuda, A. Z., Mokhtar, T. A., Moos, C., Omar, O. M., Rasheed, M., Rosiak, U., Salem, M., Schmidt, M., Schmitt, M., Stoffers, P., Shata, A. M., Themann, S., and Weldeab, S.: Report and preliminary results of Meteor cruise M 44/3 Aqaba (Jordan) - Safaga (Egypt) - Dubá (Saudia Arabia) - Suez (Egypt) - Haifa (Israel), Berichte aus dem Fachbereich Geowissenschaften der Universität Bremen, 149, pp. 135, 2000.

Pätzold, J., Moammar, M. O., Al Farawati, R., Al Hazmi, Y. M. M., Al Otibi, A., Antunes, A., Arz, H. W., Berger, J., Botz, 
R., Donner, B., Erhardt, A., Garbe-Schönberg, C.-D., Ghandourah, M., Hübscher, C., Kahl, G., Klann, M., Klauke, S., Klitzke, U., Legge, H. L., Lichowski, F., Schewe, F., Schmidt, M., Schmitt, M., Seeberg-Elverfeldt, I. A., and Truscheit, T.: Black Sea - Mediterranean - Red Sea, Part 3, Cruise No. 52, Leg 3, 10-27 March 2002, Limassol-Limassol, in: METEORBerichte, Black Sea - Mediterranean - Red Sea, Cruise No. 52, 2 January-27 March 2002, edited by: Pätzold, J., Bohrmann, G., and Hübscher, C., Universität Hamburg, Hamburg, pp. 62; available under: http://www.marum.de/M52_-_Schwarzes_Meer_ -_Mittelmeer_-_Rotes_Meer.html, 2003.

Pautot, G., Guennoc, P., Coutelle, A., and Lyberis, N.: Discovery of a large brine deep in the northern Red Sea, Nature, 310, 133-136, 1984.

Pike, J. and Kemp, A. E. S.: Preparation and analysis techniques for studies of laminated sediments, in: Palaeoclimatology and Palaeoceanography from laminated sediments, edited by: Kemp, A. E. S., Geological Society, Special Publication, pp. 37-48, 1996a.

Pike, J. and Kemp, A. E. S.: Silt aggregates in laminated marine sediment produced by agglutinated foraminifera, J. Sed. Res., 66(3), 625-631, 1996b.

Reineck, H.-E. and Singh, I. B.: Depositional Sedimentary Environments, Springer-Verlag, Berlin, Heidelberg, 1980.

Schimmelmann, A., Lange, C. B., and Berger, W. H.: Climatically controlled marker layers in Santa Barbara Basin sediments and fine-scale core-to-core correlation, Limnol. Oceanogr., 35(1), 165-173, 1990.
Seeberg-Elverfeldt, I. A., Lange, C. B., Arz, H. W., Pätzold, J., and Pike, J.: The significance of diatoms in the formation of laminated sediments in the Shaban Deep, Northern Red Sea, Mar. Geol., 209(1-4), 279-301, 2004a.

Seeberg-Elverfeldt, I. A., Lange, C. B., and Pätzold, J.: Preservation of siliceous microplankton in surface sediments of the northern Red Sea, Mar. Micropal., 51(3/4), 193-211, 2004b.

Seeberg-Elverfeldt, I. A., Lange, C. B., Pätzold, J., and Arz, H. W.: Possible role of solar forcing upon laminated sediments in the Shaban Deep, northern Red Sea, in: System Earth - Biosphere Coupling, edited by: Freiwald, A., Röhling, H.-G., and Löffler, S.-B., Schriftreihe der Deutschen Gesellschaft für Geowissenschaften, Deutsche Gesellschaft für Geowissenschaften, Erlangen, Germany, pp. 353, 2005.

Shaikh, E. A., Roff, J. C., and Dowidar, N. M.: Phytoplankton ecology and production in the Red Sea off Jiddah, Saudi Arabia. Mar. Biol., 92, 405-416, 1986.

Stoffers, P., Botz, R., and Scholten, J.: Isotope Geochemistry of Primary and Secondary Carbonate Minerals in the ShabanDeep (Red Sea), in: Sediments and Environmental Geochemistry, edited by: Helnig, D., Rothe, P., Förster, U., and Stoffers, P., Springer, Berlin, 83-94, 1990.

Yoon, W. D., Kim, S. K., and Han, K. N.: Morphology and sinking velocities of fecal pellets of copepod, molluscan, euphausiid, and salp taxa in the northeastern tropical Atlantic, Mar. Biol., 139, 923-928, doi:10.1007/s002270100630, 2001. 